\title{
Colonisation success of introduced oysters is driven by wave- related exposure
}

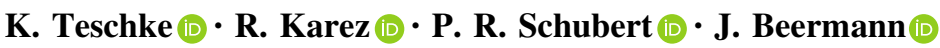

Received: 20 December 2019/Accepted: 21 March 2020/Published online: 28 March 2020

(C) The Author(s) 2020

\begin{abstract}
The Pacific oyster, Magallana gigas, is an extremely successful invader with established populations in marine and estuarine habitats almost all over the world. Ecological implications of the introduction of this species to indigenous communities are well documented. However, the processes by which this species successfully establishes in a recipient com-
\end{abstract}

Electronic supplementary material The online version of this article (https://doi.org/10.1007/s10530-020-02246-0) contains supplementary material, which is available to authorized users.

K. Teschke $(\bowtie) \cdot J$. Beermann

Alfred Wegener Institute, Helmholtz Centre for Polar and Marine Research, Am Handelshafen 12,

27570 Bremerhaven, Germany

e-mail: Katharina.Teschke@awi.de

K. Teschke $\cdot$ J. Beermann

Helmholtz Institute for Functional Marine Biodiversity at the University Oldenburg (HIFMB), Ammerländer

Heerstraße 231, 26129 Oldenburg, Germany

R. Karez

State Agency for Agriculture, Environment and Rural Areas of Schleswig-Holstein, Hamburger Chaussee 25, 24220 Flintbek, Germany

P. R. Schubert

GEOMAR Helmholtz Centre for Ocean Research Kiel, Düsternbrooker Weg 20, 24105 Kiel, Germany munity is still insufficiently understood. The early detection of the oyster at the island of Helgoland (North Sea) provided the ideal opportunity to investigate whether physical mechanisms, such as waveexposure, influence their successful colonisation. We hypothesized that oyster colonisation benefits from wave-protected conditions. For this purpose, we evaluated colonisation success of $M$. gigas among wave-protected sites and wave-exposed sites along the island's pier system. The densities of $M$. gigas were significantly higher at wave-protected sites than at wave-exposed sites, and the frequency distributions of oyster lengths indicated better growth and higher survival rates in the harbours. This higher colonisation success at wave-protected sites may be explained by the relative retention time of water masses in the harbours, probably resulting in both reduced larval drift and lower energy demands for secretion formation (i.e. firmer binding to the substrate). The fact that the density of $M$. gigas can vary greatly on small spatial scales depending on exposure corroborates a multiple exposure sampling approach to monitor oyster populations in order to avoid potential overestimations of population sizes in given areas.

Keywords Magallana gigas - Wave exposure · North sea $\cdot$ Abundance $\cdot$ Length frequency distribution · Neobiota 


\section{Introduction}

Globalisation and climate change have accelerated the spread of non-indigenous species (NIS) in the world's oceans in the last decades (e.g. Bellard et al. 2013; Hulme 2017). Invasive species can lead to significant changes in communities or even entire ecosystems, e.g. through loss of biodiversity and changes in ecosystem functions and services (e.g. Sala et al. 2000; Butchart et al. 2010). The colonisation success of NIS depends on several factors, which fall broadly into two categories: (1) the species' autecological characteristics and competitive strength in coping with environmental conditions (Byers 2002; Stachowicz et al. 2002), and (2) interspecific interactions in the newly introduced area (Kennedy et al. 2002; Meiners et al. 2004).

The Pacific oyster Magallana gigas (formerly Crassostrea gigas; Salvi and Mariottini 2016; Bayne et al. 2017) is one of the most successful marine invaders with established populations beyond its natural range (see Ruesink et al. 2005 and references therein). Pacific oysters are well established in different habitat types from sandy and muddy tidal flats, where they preferably attach to the blue mussel or to each other (Diederich 2005), to rocky shores (Ruesink 2007) and artificial hard substrates such as rocky dikes and harbour facilities (Smaal et al. 2009).

The species had been introduced to various localities along the North Sea coast during past decades for aquaculture activities (e.g. Oosterschelde estuary, 1964; North Frisian Wadden Sea near the island of Sylt, 1986; see Reise 1998; Wehrmann et al. 2000). Its successful reproduction and the recruitment of oysters outside of the aquaculture facilities on intertidal mussel beds and artificial hard substrates led to their spread in the Wadden Sea until juvenile Pacific oysters were found for the first time in the centre of the German Bight, i.e. at the island of Helgoland in 2003 (Franke and Gutow 2004).

The changes caused by the introduction of the Pacific oyster on native assemblages are well documented (e.g. Ruesink et al. 2005; Green and Growe 2014). However, less effort has been devoted to understand the underlying processes by which the oysters successfully establish within recipient assemblages. The timely discovery of the invader at Helgoland created the ideal opportunity to study how densities of Pacific oysters in a new area vary on small spatial scales (hundreds of metres to few kilometres) and whether physical mechanisms, such as waveexposure, affect successful establishment.

As recruitment of Pacific oysters seems to be enhanced in wave-protected conditions (Robinson et al. 2005; Ruesink 2007), we tested if waveprotected artificial harbours provide particularly beneficial conditions for the species. For this purpose, we compared the abundances and length-frequency distributions of $M$. gigas between wave-protected sites and wave-exposed sites along the pier system around the island of Helgoland.

\section{Material and methods}

Study sites

Seven wave-protected sites (i.e. in the two harbours of the island) and seven wave-exposed sites (i.e. outside the harbours) were randomly chosen. The 14 sites were distributed along the almost $6000 \mathrm{~m}$ long pier system of the island of Helgoland in the German Bight, North Sea $\left(54^{\circ} 11^{\prime} \mathrm{N}, 7^{\circ} 53^{\prime} \mathrm{E}\right.$; Fig. 1). The maximum water velocity (as an indication of exposure) at the wave-exposed sites of Helgoland was more than two times higher than at the wave-protected sites (Molis et al. 2015). Species assemblages did not differ among study sites, being predominantly a mosaic of barnacles, green algae (Ulva spp.) and red seaweeds (Porphyra spp., Mastocarpus stellatus, Chondrus crispus) in the mid-to-low intertidal. Ten replicate quadrats $\left(0.25 \mathrm{~m}^{2}\right)$ were placed at the vertical pier walls at each site by SCUBA divers. In each replicate quadrat, all oysters were counted and measured (maximum shell length, to the nearest $1.0 \mathrm{~mm}$ ) in 2005 and 2006. This procedure was repeated in 2012. Each of the three sampling campaigns took place in late spring or summer months. In total, 140 quadrats were sampled for the two different degrees of exposure per year (10 replicates $\times 7$ sites $\times 2$ exposures $=140$ ). Further details of the sampling campaigns are shown in the Supplement (see Tab. S1).

\section{Data analysis}

The effect of wave exposure on the abundance of Magallana gigas over time was tested with a repeatedmeasures ANOVA using the seven replicate sites for each wave exposure. The ten sampling quadrats 


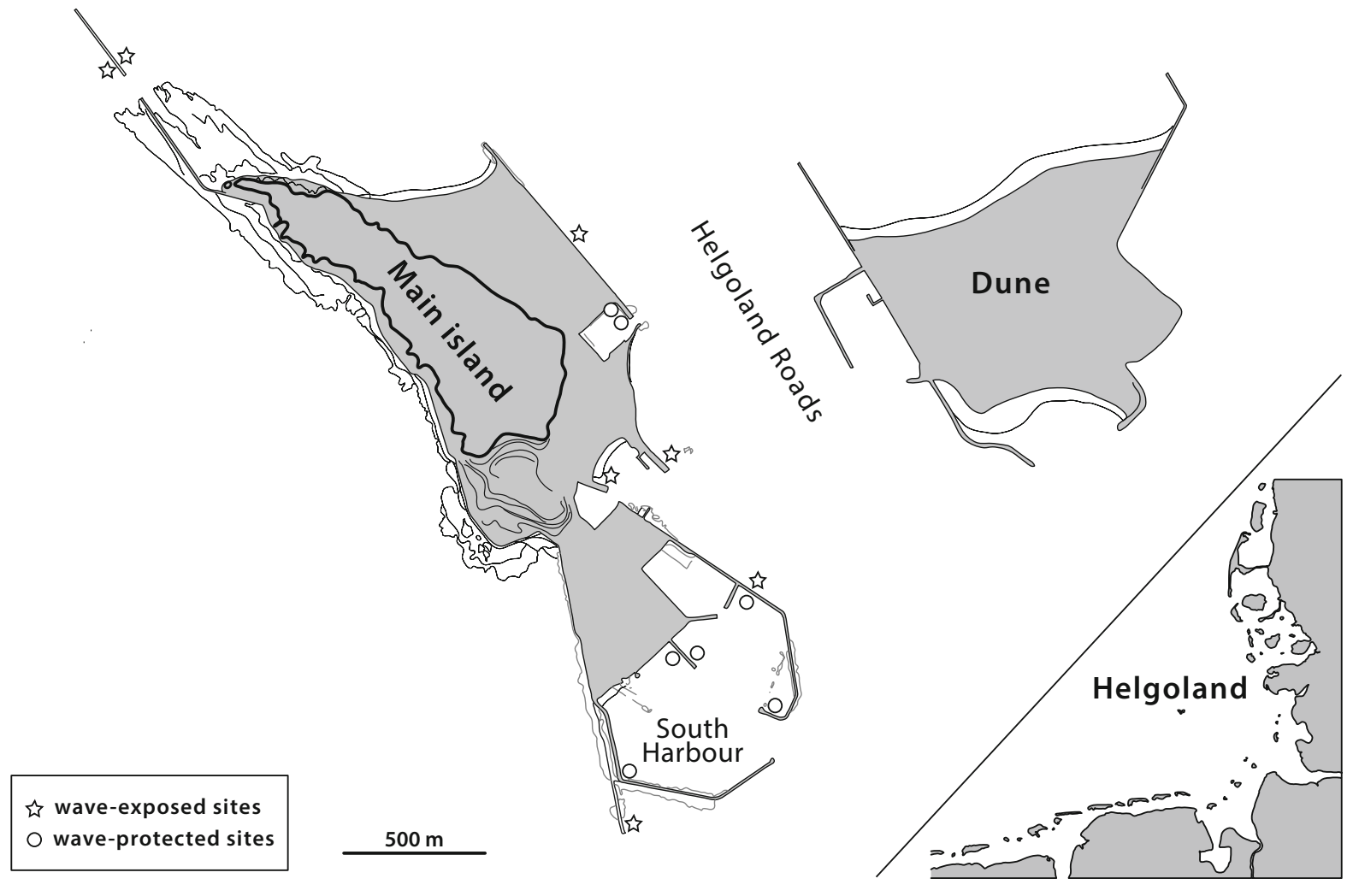

Fig. 1 Map of Helgoland and its location in the German Bight, North Sea (bottom right corner). Symbols indicate the positions of the wave-exposed (asterisks) and wave-protected sites (circles). (Modified from Beermann 2014)

were averaged for each site. Time (factor levels: '2005', '2006', '2012') was treated as repeated measures within-subject factor, and the wave exposure (2 factor levels: 'protected', 'exposed') was a between-subject factor. Prior to ANOVA, the data were tested for homogeneity of variances using Cochran's $\mathrm{C}$ test. In case of heteroscedasticity, the data were $\log (\mathrm{x}+1)$-transformed.

The analysis of the different size classes of M. gigas was conducted by comparing the medians of frequencies via Kruskal-Wallis according to Sokal and Rohlf (1995).

All tests were performed with the software package Statistica Version 10.0 MR1 (StatSoft Inc., Tulsa, Oklahoma, USA).

\section{Results}

The abundances of Magallana gigas were significantly higher at wave-protected sites than at wave- exposed sites $\left(\mathrm{F}_{1,12}=69.17, p<0.001\right)$ (Fig. 2). This pattern was consistent throughout time-oyster individuals were significantly more abundant at waveprotected than at wave-exposed sites in 2005 $(p<0.05)$ and $2006(p<0.05)$ as well as in 2012 $(p<0.001)$. At the same time, oyster abundances at both wave-protected and wave-exposed sites increased distinctly between 2005/2006 and 2012 (more than 15 and 10 times respectively).

The length-frequency distributions of oysters at wave-protected sites revealed a similar pattern each year, with most individuals in the 10-20 mm size class $\left(2005: \mathrm{H}_{\mathrm{K}-\mathrm{W}}=76.53, p<0.001 ; 2006: \mathrm{H}_{\mathrm{K}-\mathrm{W}}=75.91\right.$, $p<0.001 ; 2012: \mathrm{H}_{\mathrm{K}-\mathrm{W}}=58.81, p<0.001$ ) (Fig. 3). Larger individuals $(50 \mathrm{~mm}$ and larger) increased slightly over the years, and individuals larger than $80 \mathrm{~mm}$ were not found until 2012. In 2005, no individuals were detected at wave-exposed sites (Fig. 3). In the following year, most individuals were again found in the 10-20 mm size class as at the waveprotected sites $\left(\mathrm{H}_{\mathrm{K}-\mathrm{W}}=43.87, p<0.001\right)$. In 2012, the 


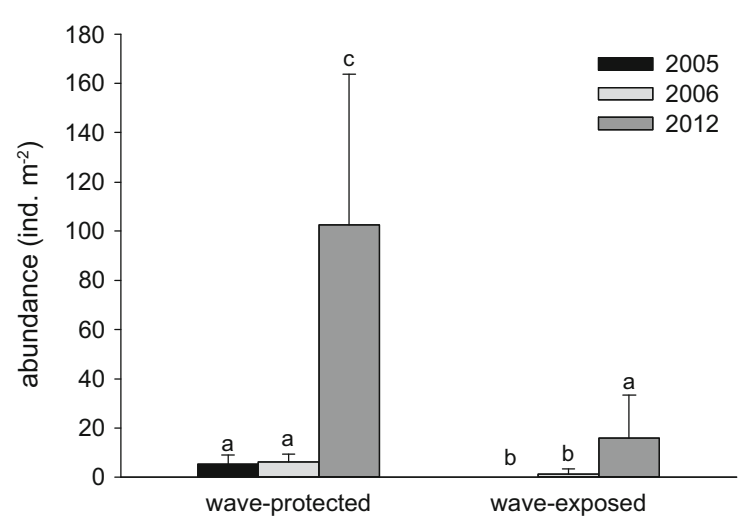

Fig. 2 Effect of wave exposure on abundance of Magallana gigas through time. Error bars are standard deviation among replicated sites. Student-Newman-Keuls (SNK) post hoc test was run for wave exposure and year combinations. Different letters indicate statistically significant differences $(p<0.001)$ between means of replicated sites per exposure per year $(n=7)$. Please note that no individuals were detected at wave-exposed sites in 2005

first two size classes (i.e. 0-10 and 10-20 mm) differed significantly from the other size classes $\left(\mathrm{H}_{\mathrm{K}-\mathrm{W}}=91.00\right.$, $p<0.001$, where only very few individuals per class were found.

\section{Discussion}

\section{Abundances}

Higher abundances of Magallana gigas were observed at wave-protected sites. This contradicts common distribution patterns of sessile filter-feeders, mainly mytilids, barnacles and tubeworms, which are known to predominate especially wave-exposed areas caused by an increased replenishment of food, higher oxygenation inputs and/or decreased predator pressure due to wave shock (e.g. Scrosati and Heaven 2008; Arribas et al. 2014).

Oysters seem to be an exception to the general pattern of filter feeders. An increased occurrence of $M$. gigas and other oyster species under sheltered conditions has been reported, for example, from coastal marine (Ruesink 2007) and estuarine areas (Robinson et al. 2005) as well as from harbour sites (Blockley and Chapman 2008). The success of oyster colonisation at wave-protected sites may be explained by (1) the relative retention of water masses in the harbours and the associated reduced drift of the larvae and (2) the reduced whiplash effect on newly settled larvae, i.e. their removal by wave-induced movement of algal thalli (e.g. Leonard 1999; Beermann et al. 2013). This may also explain that it obviously took longer for oysters to settle at exposed sites, as no oysters were found here in 2005, while a few individuals (up to 11 individuals $/ 0.25 \mathrm{~m}^{2}$ ) were found at all wave-protected sites.

\section{Length frequency distributions}

The observed patterns in length frequency distributions indicated better growth and higher survival rates at wave-protected sites, i.e. larger individuals of $M$. gigas occurred almost exclusively in the harbours. This is in contrast to some previous findings, which demonstrated high growth potential of oysters (e.g. Brown 1988; Campbell and Hall 2019) and other bivalves (Bayne and Newell and references therein 1983) primarily through increased food supply more likely to be found in habitats exposed to waves and currents. Large oysters, however, have also been detected in sheltered waters with relatively low food supply associated with a decoupling of shell and somatic growth, i.e. good shell growth, but underdeveloped somatic growth (e.g. Brown and Hartwick 1988; Chávez-Villalba et al. 2010). Furthermore, a high wave load at the exposed sites may have resulted in reallocation of energy from shell/soft tissue growth into secretion formation-for a firmer binding to the substrate-as shown for other bivalves, e.g. Mytilus galloprovincialis and the black-lip pearl oyster, Pinctada margaritifera (e.g. Babarro and Carrington 2011; Kishore et al. 2014).

A seemingly increased mortality rate of $M$. gigas at wave-exposed sites appears to be primarily caused by processes directly related to wave exposure, such as detachment/dislodgment from the substrate (e.g. Alvarado and Castilla 1996). Different predation mortality between the two different exposure levels is rather unlikely, as in the North Sea a generally low pressure by the main benthic predators, the starfish Asterias rubens and the shore crab Carcinus maenas, which prefer blue mussels to oysters, is reported (Diederich 2005).

In conclusion, oyster populations of Magallana gigas are characterized by large variation on small spatial scales in non-native habitats. Wave exposure 
Fig. 3 Length frequencies (size class interval $=10 \mathrm{~mm}$ ) of Magallana gigas at waveprotected (a) and waveexposed sites (b) in 2005 (1), 2006 (2) and 2012 (3).

Please note that no individuals were detected at wave-exposed sites in 2005 (b1)
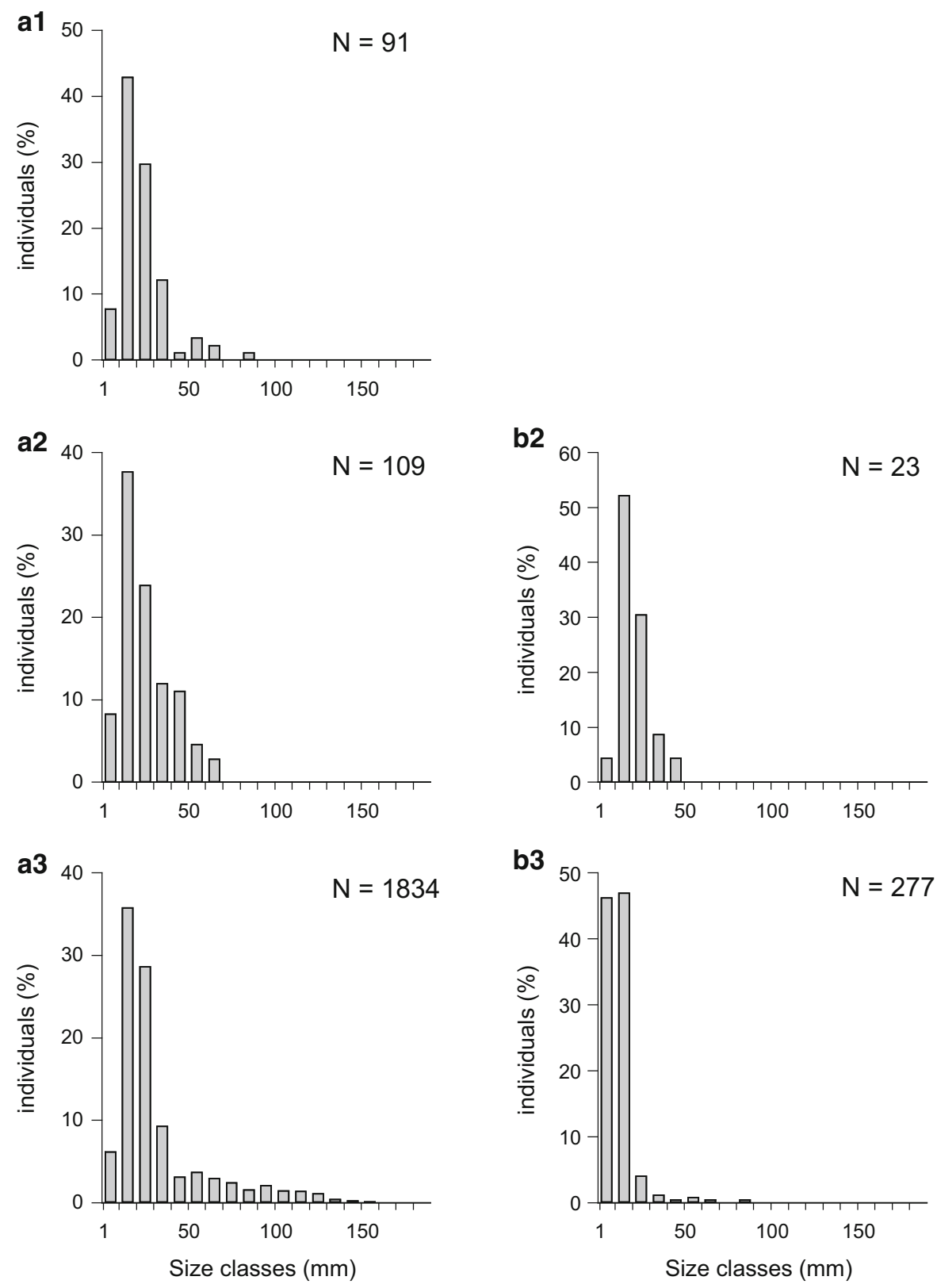

b3

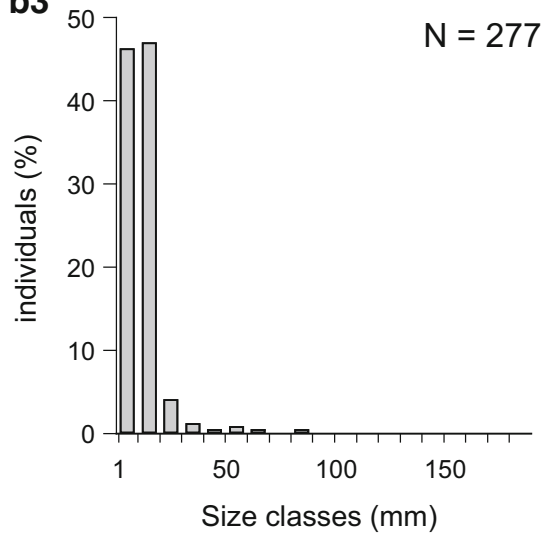

seems to have a profound impact on colonisation, and thus, establishment success. Artificial harbours that are largely protected from wave load, can serve as a preferred oyster habitat. Consequently, monitoring programmes that aim at capturing NIS must be carefully evaluated, as surveys are often restricted to harbours and marinas (e.g. Rohde et al. 2017; Kraus et al. 2019). We argue that potential overestimations of local oyster populations can be avoided by a multipleexposure sampling approach.
Acknowledgements Open Access funding provided by Projekt DEAL. We gratefully thank the diving crew of the Biological Station Helgoland, especially C. Wanke and S. Brandt, and the crew of the research vessel "Diker", especially Captain A. Köhn, for their invaluable help and constant support, without whom the study could not have been carried out. We thank M. de Kluijver for his observations of the Pacific oyster during his dives around Helgoland, which gave the impetus for this study. The 2012 sampling campaign was carried out via contract of the State Agency for Agriculture, Nature and Rural Areas (LLUR) of Schleswig-Holstein to Inka Bartsch (Alfred Wegener Institute). We gratefully acknowledge the financing. 
The sampling in 2012 was carried out with the help of scientific diver Christian Howe. We thank two anonymous reviewers for constructive comments on the manuscript.

Open Access This article is licensed under a Creative Commons Attribution 4.0 International License, which permits use, sharing, adaptation, distribution and reproduction in any medium or format, as long as you give appropriate credit to the original author(s) and the source, provide a link to the Creative Commons licence, and indicate if changes were made. The images or other third party material in this article are included in the article's Creative Commons licence, unless indicated otherwise in a credit line to the material. If material is not included in the article's Creative Commons licence and your intended use is not permitted by statutory regulation or exceeds the permitted use, you will need to obtain permission directly from the copyright holder. To view a copy of this licence, visit http://creativecommons.org/licenses/by/4.0/.

\section{References}

Alvarado JL, Castilla JC (1996) Tridimensional matrices of mussels Perumytilus purpuratus on intertidal platforms with varying wave forces in central Chile. Mar Ecol Prog Ser 133:135-141. https://doi.org/10.3354/meps133135

Arribas LP, Donnarumma L, Palomo MG, Scrosati RA (2014) Intertidal mussels as ecosystem engineers: their associated invertebrate biodiversity under contrasting wave exposures. Mar Biodiv 44:203-211. https://doi.org/10.1007/ s12526-014-0201-z

Babarro JMF, Carrington E (2011) Byssus secretion of Mytilus galloprovincialis: effect of site at macro- and micro-geographical scales within Ría de Vigo (NW Spain). Mar Ecol Prog Ser 435:125-140. https://doi.org/10.3354/meps09200

Bayne BL, Newell RC (1983) Physiological energetics of marine molluscs. In: Saleuddin ASM, Wilbur KM (eds) The Mollusca 4, physiology, Part 1. Academic Press, New York, pp 407-515

Bayne BL, Ahrens M, Allen SK et al (2017) The proposed dropping of the genus Crassostrea for all pacific cupped oysters and its replacement by a new genus Magallana: a dissenting view. J Shellfish Res 36:545-547. https://doi. org/10.2983/035.036.0301

Beermann J (2014) Spatial and seasonal population dynamics of sympatric Jassa species (Crustacea, Amphipoda). J Exp Mar Biol Ecol 459:8-16. https://doi.org/10.1016/j.jembe. 2014.05.008

Beermann AJ, Ellrich JA, Molis M, Scrosati RA (2013) Effects of seaweed canopies and adult barnacles on barnacle recruitment: the interplay of positive and negative influences. J Exp Mar Biol Ecol 448:162-170. https://doi.org/ 10.1016/j.jembe.2013.07.001

Bellard C, Thuiller W, Leroy B, Genovesi P, Bakkenes M, Courchamp F (2013) Will climate change promote future invasions? Glob Change Biol 19:3740-3748. https://doi. org/10.1111/gcb.12344

Blockley DJ, Chapman MG (2008) Exposure of seawalls to waves within an urban estuary: effects on intertidal assemblages. Austral Ecol 33:168-183. https://doi.org/10. 1111/j.1442-9993.2007.01805.x

Brown JR (1988) Multivariate analyses of the role of environmental factors in seasonal and site-related growth variation in the Pacific oyster Crassostrea gigas. Mar Ecol Prog Ser 45:225-236. https://doi.org/10.3354/meps045225

Brown JR, Hartwick EB (1988) Influences of temperature, salinity and available food upon suspended culture of the Pacific oyster, Crassostrea gigas, I. Absolute and allometric growth. Aquaculture 70:231-251. https://doi.org/ 10.1016/0044-8486(88)90099-3

Butchart SHM, Walpole M, Collen B et al (2010) Global biodiversity: indicators of recent declines. Science 328:1164-1168. https://doi.org/10.1126/science.1187512

Byers JE (2002) Physical habitat attribute mediates biotic resistance to non-indigenous species invasion. Oecologia 130:146-156. https://doi.org/10.1007/s004420100777

Campbell MD, Hall SG (2019) Hydrodynamic effects on oyster aquaculture systems: a review. Rev Aquacult 11:896-906. https://doi.org/10.1111/raq.12271

Chávez-Villalba J, Arreola-Lizárraga A, Burrola-Sánchez S, Hoyos-Chairez F (2010) Growth, condition, and survival of the Pacific oyster Crassostrea gigas cultivated within and outside a subtropical lagoon. Aquaculture 300:128-136. https://doi.org/10.1016/j.aquaculture.2010.01.012

Diederich S (2005) Invasion of Pacific oysters (Crassostrea gigas) in the Wadden Sea: competitive advantage over native mussels. Dissertation, Christian-Albrechts-University, Kiel

Franke HD, Gutow L (2004) Long-term changes in the macrozoobenthos around the rocky island of Helgoland (German Bight, North Sea). Helgol Mar Res 58:303-310. https://doi. org/10.1007/s10152-004-0193-3

Green DS, Growe TP (2014) Context- and density-dependent effects of introduced oysters on biodiversity. Biol Invasions 16:1145-1163. https://doi.org/10.1007/s10530-0130569-x

Hulme PE (2017) Climate change and biological invasions: evidence, expectations, and response options. Biol Rev 92:1297-1313. https://doi.org/10.1111/brv.12282

Kennedy TA, Naeem S, Howe KM, Knops JMH, Tilman D, Reich P (2002) Biodiversity as a barrier to ecological invasion. Nature 417:636-638. https://doi.org/10.1038/ nature 00776

Kishore P, Hunter J, Zeng C, Southgate PC (2014) The effects of different culture apparatuses and current velocities on byssus production by the black-lip pearl oyster, Pinctada margaritifera. Aquaculture 434:74-77. https://doi.org/10. 1016/j.aquaculture.2014.07.027

Kraus R, Ninčević-Gladan Ž, Auriemma R et al (2019) Strategy of port baseline surveys (PBS) in the Adriatic Sea. Mar Pollut Bull 147:47-58. https://doi.org/10.1016/j.marpolb ul.2018.08.067

Leonard GH (1999) Positive and negative effects of intertidal algal canopies on recruitment and survival of barnacles. Mar Ecol Prog Ser 178:241-249. https://doi.org/10.3354/ meps 178241

Meiners SJ, Cadenasso ML, Pickett STA (2004) Beyond biodiversity: individualistic controls of invasion in a selfassembled community. Ecol Lett 7:121-126. https://doi. org/10.1111/j.1461-0248.2003.00563.x 
Molis M, Scrosati RA, El-Belely EF, Lesniowski TJ, Wahl M (2015) Wave-induced changes in seaweed toughness entail plastic modifications in snail traits maintaining consumption efficacy. J Ecol 103:851-859. https://doi.org/10.1111/ 1365-2745.12386

Reise K (1998) Pacific oysters invade mussel beds in the European Wadden Sea. Senckenb Marit 28:167-175. https://doi.org/10.1007/BF03043147

Robinson TB, Griffiths CL, Tonin A, Bloomer P, Hare MP (2005) Naturalized populations of oysters, Crassostrea gigas along the South African coast: Distribution, abundance and population structure. J Shellfish Res 24:443450. https://doi.org/10.2983/0730-8000(2005)24[443:NPO OCG]2.0.CO;2

Rohde S, Schupp PJ, Markert A, Wehrmann A (2017) Only half of the truth: Managing invasive alien species by rapid assessment. Ocean Coast Manag 146:26-35. https://doi. org/10.1016/j.ocecoaman.2017.05.013

Ruesink JL (2007) Biotic resistance and facilitation of a nonnative oyster on rocky shores. Mar Ecol Prog Ser 331:1-9. https://doi.org/10.3354/meps331001

Ruesink JL, Lenihan HS, Trimble AC, Heiman KW, Micheli F, Byers JE, Kay MC (2005) Introduction of non-native oysters: ecosystem effects and restoration implications. Annu Rev Ecol Evol Syst 36:643-689. https://doi.org/10. 1146/annurev.ecolsys.36.102003.152638

Sala OE, Chapin FS, Armesto JJ, Berlow E, Bloomfield J, Dirzo R, Huber-Sanwald E, Huenneke LF, Jackson RB, Kinzig A, Leemans R, Lodge DM, Mooney HA, Oesterheld M, LeRoy PN, Sykes MT, Walker BH, Walker M, Wall DH (2000) Global biodiversity scenarios for the year 2100. Science 287:1770-1774. https://doi.org/10.1126/science. 287.5459.1770
Salvi D, Mariottini P (2016) Molecular taxonomy in 2D: a novel ITS2 rRNA sequence-structure approach guides the description of the oysters' subfamily Saccostreinae and the genus Magallana (Bivalvia: Ostreidae). Zool J Linn Soc 179:263-276. https://doi.org/10.1111/zoj.12455

Scrosati R, Heaven C (2008) Trends in abundance of rocky intertidal seaweeds and filter feeders across gradients of elevation, wave exposure, and ice scour in eastern Canada. Hydrobiologia 603:1-14. https://doi.org/10.1007/s10750007-9160-8

Smaal AC, Kater BJ, Wijsman J (2009) Introduction, establishment and expansion of the Pacific oyster Crassostrea gigas in the Oosterschelde (SW Netherlands). Helgol Mar Res 63:75-83. https://doi.org/10.1007/s10152-008-0138-3

Sokal RR, Rohlf FJ (1995) Biometry: The principles and practice of statistics in biological research, 3rd edn. WH Freeman and Company, New York

Stachowicz JJ, Fried H, Whitlatch RB, Osman RW (2002) Biodiversity, invasion resistance, and marine ecosystem function: reconciling pattern and process. Ecology 83: 2575-2590. https://doi.org/10.1890/0012-9658(2002)083[25 75:BIRAME]2.0.CO;2

Wehrmann A, Herlyn M, Bungenstock F, Hertweck G, Millat G (2000) The distribution gap is closed-first record of naturally settled Pacific oysters Crassostrea gigas in the East Frisian Wadden Sea, North Sea. Senckenb Marit 30:153160. https://doi.org/10.1007/BF03042964

Publisher's Note Springer Nature remains neutral with regard to jurisdictional claims in published maps and institutional affiliations. 